\title{
Development of path indices for enhancing sugarcane selection program
}

\author{
Amjad Ali $^{1 *}$, Mohammad Tahir ${ }^{2}$, Nur Ul Haq ${ }^{2}$, Muhammad Ismail ${ }^{2}$ and \\ Nabeela Hayat ${ }^{3}$ \\ 1. Agriculture Research Station Swabi, Khyber Pakhtunkhwa-Pakistan \\ 2. Sugar Crops Research Institute Mardan, Khyber Pakhtunkhwa-Pakistan \\ 3. CECOSS University Peshawar-Pakistan \\ *Corresponding author's email: srobreeding@gmail.com \\ Citation \\ Amjad Ali, Mohammad Tahir, Nur Ul Haq, Muhammad Ismail and Nabeela Hayat. Development of path indices for \\ enhancing sugarcane selection program. Pure and Applied Biology. Vol. 10, Issue 4, pp1088-1094. \\ http://dx.doi.org/10.19045/bspab.2021.100113

\begin{tabular}{llll}
\hline \hline Received: 01/10/2020 & Revised: 18/12/2020 & Accepted: 04/01/2021 & Online First: 12/01/2021 \\
\hline \hline
\end{tabular}

\section{Abstract}

The present investigation was carried out to develop path index using the relationship of contributing traits and cane yield. Development of path indices using linear regression equation followed by path analysis tells about the relationship of the dependent and independent parameters and better performing genotype can be selected. The study was conducted at sugar crops research institute Mardan during 2012-13 and 2013-14 on two plant crops. The experiments were arranged in RCB Design with three replications using 14 sugarcane genotypes with two check cultivars (Mardan-93 and CP/77-400). Path analysis showed that number of millablecane (0.39), internodes length (0.32), number of nodes (0.14), plant height (0.13) and number of tillers $(0.12)$ had the direct positive effect on cane yield on phenotypic level. In case of genotypic level number of millablecane (0.63), plant height (0.42) and number of tillers (0.21) had the highest direct positive effect on cane yield. This showed that these characters are the most essential constituents of cane yield. Genotype MS-91-CP-523(240.39) followed by S-92-US-72 (205.21) have the highest path index values and performed better than the rest of the genotype. The parameters having direct effect on cane yield must be given more importance in the breeding and selection strategies. Research should be focused on the selection of genotypes which has good performance both under plant and ratoon crops conditions. The genotypes with good performance may be tested further.

Keywords: Direct and indirect effect; Path coefficients; Plant crop; Selection criteria

Introduction

Sugarcane is cultivated on about 26 million hectares, in more than 90 countries, with a production of $1.83 \times 109$ tons. Pakistan ranked fifth with a production of 63749 TMT (Thousand Metric Tons) and about 3.3\% of world total production [1].

In breeding sugarcane thousands of seedlings are produced and evaluated from crosses every year and superior seedlings are selected for further evaluation [2]. Selection is usually carried out for the development of new sugarcane varieties. The study of relationship of different characters with cane yield is essential, so that an appropriate and efficient selection strategy could be adopted for improvement. Therefore the knowledge about the associations that occur among the different traits and cane yield is important. Complex characters can be studied better by 
knowing the direct and indirect effect of interrelated components through path analysis. [3]. Suitable genotypes for a locality can be identified when selection criteria based on the characters having important contribution for the desired characters are made.

Path coefficient analysis splits the correlation into direct and indirect effect on yield and helps in development of selection criteria to improve cane yield [4]. While path indices developed by the direct genotypic effects in path coefficient analysis tells about the performance of the genotypes under different crops conditions.

The study was conducted to study the interrelation of different characters on cane yield and select a superior genotype by adopting the selection criteria based on path coefficient analysis.

Two genotypes were selected for future breeding programme on the basis of high path indices i.e. MS-91-CP-523(240.39) followed by S-92-US-72 (205.21) and performed better than the rest of the genotype. The forecast indices obtained in the study could aid in sugarcane selection and breeding programs under the agro climatic conditions of Peshawar valley of Khyber Pakhtunkhwa, Pakistan.

\section{Materials and Methods}

The study was conducted at the Sugar Crops Research Institute (SCRI), Mardan, Pakistan located at $34^{\circ}$ North latitude and $72^{\circ}$ East longitude, altitude 283 meter, total rainfall $696 \mathrm{~mm}$ (summer $488 \mathrm{~mm}$, winter $208 \mathrm{~mm}$ ), summer mean temperature $39.8^{\circ} \mathrm{C}$, winter mean temperature $1.33^{\circ} \mathrm{C}$ with a mean relative humidity of $60.8 \%$ on sugarcane plant crop during 2012-13 and 2013-14. Materials comprised 14 sugarcane genotypes and two check cultivars arranged in a randomized complete block design with three replications. These genotypes were advanced from previous selection stages with diverse origins. A plot for each genotype was $10 \mathrm{~m}$ long and $6.7 \mathrm{~m}$ wide, having 7 rows (150 buds per row) with a row-to-row distance of 90 $\mathrm{cm}$. Recommended dose of fertilizer i.e. N, $\mathrm{P}_{2} \mathrm{O}_{5}$ and $\mathrm{K}_{2} \mathrm{O}$ at rates of 150: 100:100 kg ha

${ }^{1}$ was given to the crop. Data were recorded, on 7 different traits of growth, cane and yield characters.

Traits measurement and analysis

Data was recorded on the following traits.

\section{Number of tillers}

The actual numbers of tillers in the central row were counted for each plot.

\section{Plant height}

The data was recorded on five randomly selected plants with the help of a tap in centimeters and then averaged. The data was taken in $1^{\text {st }}$ week of July.

\section{Number of nodes}

Random selection was performed and 5 plants were selected for each genotype. Number of nodes for each genotype was counted and averaged.

\section{Internode length}

The data was also taken in centimeters. The $5^{\text {th }}$ internode from the base was selected for five randomly selected stalks and averaged.

\section{Cane diameter}

A digital Vernier Caliper $(0-150 \mathrm{~mm}$ digital caliper. Stainless Hardened. Germany) was used for this data. Diameter of the stalk was measured for each of the 5 randomly selected stalks at the $5^{\text {th }}$ internode from the base.

\section{Number of millablecane}

This data was taken by counting the number of millablecane in the mid row (without the undeveloped tillers).

\section{Cane yield (Tons/ha)}

This data was taken by weighing the cane without trash per plot in kilograms and converting in to tons / ha by the following formula.

Caneyield $=\left(\frac{\mathrm{xX} 10000}{\text { plot size X 1000 }}\right)$

Where " $x$ " is the yield in kg per plot [5].

Statistical analysis

$\mathrm{R}$ software version 2.14 was used for path analysis [4]. Dependent and independent 
variables were separated. Path index was used as selection criterion using linear regression equation. The following formula was used omitting the intercept.

$\mathrm{Y}=\mathrm{X}_{1} \mathrm{~b}_{1}+\mathrm{X}_{2} \mathrm{~b}_{2}+\mathrm{X}_{3} \mathrm{~b}_{3} \ldots \ldots \ldots . \mathrm{X}_{\mathrm{n}} \mathrm{b}_{\mathrm{n}}$.

Where

$\mathrm{X}=$ Path Coefficient

$\mathrm{b}=$ mean of observed variable

The genotypes were evaluated by using this path index as selection criterion and the top genotypes were selected as better performer for a particular character. $[6,7]$.

\section{Results}

Phenotypic path coefficient analysis measured under plant crops conditions exhibited positive direct effect of number of tillers on cane yield $(\mathrm{P}=0.12)$. It showed positive indirect effect via number of millablecane $\left(\mathrm{P}_{1,6}=0.34\right)$, internode length $\left(\mathrm{P}_{1,4}=0.26\right)$, plant height $\left(\mathrm{P}_{1,2}=0.1\right)$, and number of nodes $\left(\mathrm{P}_{1,3}=0.09\right)$. The indirect effect of number of tillers on cane yield via cane diameter $\left(\mathrm{P}_{1,5}=-0.05\right)$ is negative. Plant height showed positive direct phenotypic effect on cane yield $(\mathrm{P}=0.13)$, similarly plant height showed positive indirect effect through number of millablecane $\left(\mathrm{P}_{2,6}=\right.$ $.33)$,internode length $\left(\mathrm{P}_{2,4}=.26\right)$, number of nodes $\left(\mathrm{P}_{2,3}=.11\right)$, number of tillers $\left(\mathrm{P}_{2,1}=\right.$ 0.09). Plant height showed negative indirect effect on cane yield via cane diameter $\left(\mathrm{P}_{2,5}=\right.$ -0.08). Number of nodes showed positive direct effect of $(\mathrm{P}=0.14)$ on cane yield while it showed positive indirect effect via number of millablecane $\left(\mathrm{P}_{3,6}=0.26\right)$, internode length $\left(\mathrm{P}_{3,4}=0.2\right)$, plant height $\left(\mathrm{P}_{3,2}=0.1\right)$ and number of tillers $\left(\mathrm{P}_{3,1}=0.08\right)$. Number of nodes showed positive direct effect on cane yield $(\mathrm{P}=0.14)$ while its effect through number of millablecane $\left(\mathrm{P}_{3,6}=0.26\right)$, internodes length $\left(\mathrm{P}_{3,4}=0.20\right)$, plant height $\left(\mathrm{P}_{3,2}=0.10\right)$ and number of tillers $\left(\mathrm{P}_{3,1}=0.08\right)$ is positive. Its effect via cane diameter $\left(\mathrm{P}_{3,5}=\right.$ $-0.07)$ is negative. Internode length showed positive direct effect on cane yield $(\mathrm{P}=0.32)$ at the phenotypic level. Its indirect effect via number of millablecane $\left(\mathrm{P}_{4,6}=0.31\right), 2^{\text {nd }}$ plant height $\left(\mathrm{P}_{4,2}=0.11\right)$, number of tillers $\left(\mathrm{P}_{4,1}=0.10\right)$, number of nodes $\left(\mathrm{P}_{4,3}=0.08\right)$ is positive. The indirect effect of internode length cane diameter $\left(\mathrm{P}_{4,5}=-0.09\right)$ is negative. The direct effect of cane diameter on cane yield is negative on phenotypic level $(P=-0.17)$. Indirect effect of cane diameter via number of millablecane $\left(\mathrm{P}_{5,6}=\right.$ 0.16), internode length $\left(\mathrm{P}_{5,4}=0.16\right)$, number of tillers $\left(\mathrm{P}_{5,1}=0.03\right)$, plant height $\left(\mathrm{P}_{5,2}=\right.$ $0.06)$ and number of nodes $\left(\mathrm{P}_{5,3}=0.06\right)$ is positive. Number of millablecane showed positive direct effect on cane yield $(\mathrm{P}=0.39)$. Similarly the indirect effect via number of tillers $\left(\mathrm{P}_{6,1}=0.10\right)$, plant height $\left(\mathrm{P}_{6,2}=0.11\right)$, number of nodes $\left(\mathrm{P}_{6,3}=0.09\right)$, internode length $\left(\mathrm{P}_{6,4}=0.25\right.$ is positive while the indirect effect through cane diameter $\left(\mathrm{P}_{6,5}=\right.$ 0.07 ) is negative (Table 1).

At the genotypic level, path coefficients displayed positive direct effects of number of tillers on cane yield $(\mathrm{P}=0.21)$ and its indirect effect via plant height $\left(\mathrm{P}_{1,2}=0.39\right)$, number of millablecane $\left(\mathrm{P}_{1,6}=0.62\right)$, number of nodes $\left(\mathrm{P}_{1,3}=0.02\right)$ is positive, while its indirect effect via internode length $\left(\mathrm{P}_{1,4}=\right.$ $0.20)$ and cane diameter is negative $\left(\mathrm{P}_{1,5}=-\right.$ 0.08). Plant height also showed positive direct effect on cane yield $(\mathrm{P}=0.42)$ while its indirect effect via number of tillers $\left(\mathrm{P}_{2,1}=\right.$ $0.19)$, number of millablecane $\left(\mathrm{P}_{2,6}=0.63\right)$ and number of nodes $\left(\mathrm{P}_{2,3}=0.03\right)$ is positive and it has negative indirect effect through internode length $\left(\mathrm{P}_{2,4}=-0.20\right)$ and cane diameter $\left(\mathrm{P}_{2,5}=-0.11\right)$ on cane yield. Number of nodes showed direct positive effect on cane yield $(\mathrm{P}=0.03)$ while it showed positive indirect effect via number of tillers $\left(\mathrm{P}_{3,1}=\right.$ $0.17)$, plant height $\left(\mathrm{P}_{3,2}=0.38\right)$ and number of millablecane $\left(\mathrm{P}_{3,6}=0.47\right)$ is positive. Its effect via internode length $\left(\mathrm{P}_{3,4}=-0.15\right)$ and cane diameter $\left(\mathrm{P}_{3,5}=-0.11\right)$ is negative. Internode length showed direct negative effect $(P=-0.22)$ on cane yield while its effect via number of tillers $\left(\mathrm{P}_{4,1}=0.19\right)$, plant 
height $\left(\mathrm{P}_{4,2}=0.39\right)$, number of nodes $\left(\mathrm{P}_{4,3}=\right.$ $0.02)$ and number of millablecane $\left(\mathrm{P}_{4,6}=\right.$ $0.56)$ is positive. Internode length showed negative indirect effect on cane yield via cane diameter $\left(\mathrm{P}_{4,5}=-0.14\right)$. Cane diameter showed negative $(\mathrm{P}=-0.19)$ direct effect on cane yield. It showed positive indirect effect via number of tillers $\left(\mathrm{P}_{5,1}=0.08\right)$, plant height $\left(\mathrm{P}_{5,2}=0.25\right)$, number of nodes $\left(\mathrm{P}_{5,3}=\right.$ $0.02)$ and number of millablecane $\left(P_{5,6}=\right.$ $0.39)$ is positive. The indirect effect of cane diameter via internode length is negative $\left(\mathrm{P}_{5,4}\right.$ $=-0.16)$. On the genotypic level number of millablecane also showed positive direct effect on cane yield $(\mathrm{P}=0.63)$ while its indirect effect via number of tillers $\left(\mathrm{P}_{6,1}=\right.$ $0.20)$, plant height $\left(\mathrm{P}_{6,2}=0.41\right)$, number of nodes $\left(\mathrm{P}_{6,3}=0.02\right)$ is positive and negative through internode length $\left(\mathrm{P}_{6,4}=-0.19\right)$ and cane diameter $\left(\mathrm{P}_{6,5}=0.12\right)$ (Table 2$)$.

The highest path index was observed for genotype MS-91-CP-523 with a path index value of 240.39 followed by S-92-US-72 with a path index value of 205 (Table 3).

\section{Discussion}

Path coefficient analysis revealed the importance of characters with direct and indirect effect on cane yield. Path analysis showed that number of tillers, plant height, number of millablecane, number of nodes had positive direct effect on cane yield. Selection criteria can be based on the traits having direct effect on the dependent variable (cane yield). In the field crops the parameters are correlated with each other illustrating that any of the parameter could contribute for better yield. Under plant crops conditions genotype MS-91-CP-523 was the top ranking genotype followed by S-92-US-72. Both of these genotypes performed better than the check cultivars. 8. Sanghera et al. [8] found that highest positive direct effect on cane yield is exerted by growth characters like number of shoots 240 days, number millablecanes, single cane weight and stalk diameter. Weight of millable stalks was the most significant character having the highest direct effect on sugarcane yield followed by stalk height, number of millablestalks and stalk thickness [9]. Cane characters are having the direct effect on cane yield and therefore should be given importance while selection program [10]. Cane diameter and number of stalks were more important in determining cane yield at genotypic level [3]. Therefore these characters should be kept in mind while selection and breeding for more cane yield. 
Table 1. Phenotypic direct and indirect effects of 6 characters on cane yield during 2012-13 and 2013-14

\begin{tabular}{|c|c|c|c|c|c|c|c|c|c|}
\hline \multirow{2}{*}{ S. No. } & \multirow{2}{*}{ Characters } & \multicolumn{6}{|c|}{ Indirect effect } & \multirow{2}{*}{$\begin{array}{l}\text { Direct } \\
\text { effect }\end{array}$} & \multirow{2}{*}{$\begin{array}{c}\text { Correlations } \\
\text { with cane yield }\end{array}$} \\
\hline & & 1 & 2 & 3 & 4 & 5 & 6 & & \\
\hline 1 & Number of tillers & & $\mathrm{P}_{(1,2)}, 0.1$ & $\mathrm{P}_{(1,3)} 0.09$ & $\mathrm{P}_{(1,4)}, 0.26$ & $P_{(1,5)},-0.05$ & $\mathrm{P}_{(1,6)} 0.34$ & $\mathrm{P}(0.12)$ & $0.83 * *$ \\
\hline 2 & Plant height & $\mathrm{P}_{(2,1)}, 0.09$ & & $\mathrm{P}_{(2,3)}, 0.11$ & $\mathrm{P}_{(2,4)}, 0.26$ & $\mathrm{P}_{(2,5)},-0.08$ & $\mathrm{P}_{(2,6)}, 0.33$ & $\mathrm{P}(0.13)$ & $0.81 * *$ \\
\hline 3 & Number of nodes & $\mathrm{P}_{(3,1)}, 0.08$ & $\mathrm{P}_{(3,2)}, 0.1$ & & $\mathrm{P}_{(3,4)}, 0.2$ & $\mathrm{P}_{(3,5)},-0.07$ & $\mathrm{P}_{(3,6)}, 0.26$ & $\mathrm{P}(0.14)$ & $0.67 * *$ \\
\hline 4 & Internodes Length & $\mathrm{P}_{(4,1)}, 0.10$ & $\mathrm{P}_{(4,2)}, 0.11$ & $\mathrm{P}_{(4,3)}, 0.08$ & & $\mathrm{P}_{(4,5)},-0.09$ & $\mathrm{P}_{(4,6)}, 0.31$ & $\mathrm{P}(0.32)$ & $0.74 * *$ \\
\hline 5 & Cane diameter & $\mathrm{P}_{(5,1)}, 0.03$ & $\mathrm{P}_{(5,2)}, 0.06$ & $\mathrm{P}_{(5,3)}, 0.06$ & $\mathrm{P}_{(5,4)}, 0.16$ & & $\mathrm{P}_{(5,6)}, 0.16$ & $\mathrm{P}(-0.17)$ & 0.26 \\
\hline \multirow[t]{2}{*}{6} & $\begin{array}{c}\text { Number of } \\
\text { millablecane }\end{array}$ & $\mathrm{P}_{(6,1)}, 0.10$ & $\mathrm{P}_{(6,2)}, 0.11$ & $\mathrm{P}_{(6,3)}, 0.09$ & $\mathrm{P}_{(6,4)}, 0.25$ & $\mathrm{P}(6,5),-0.07$ & & $\mathrm{P}(0.39)$ & $0.87 * *$ \\
\hline & Residual & \multicolumn{8}{|c|}{0.11} \\
\hline
\end{tabular}

Table 2. Genotypic direct and indirect effects of 6 characters on cane yield during 2012-13 and 2013-14

\begin{tabular}{|c|c|c|c|c|c|c|c|c|c|}
\hline \multirow{2}{*}{ S. No. } & \multirow{2}{*}{ Characters } & \multicolumn{6}{|c|}{ Indirect effect } & \multirow{2}{*}{$\begin{array}{c}\text { Direct } \\
\text { effect }\end{array}$} & \multirow{2}{*}{$\begin{array}{c}\text { Correlations } \\
\text { with cane yield }\end{array}$} \\
\hline & & 1 & 2 & 3 & 4 & 5 & 6 & & \\
\hline 1 & Number of tillers & & $\mathrm{P}_{(1,2)}, 0.39$ & $\mathrm{P}_{(1,3)}, 0.02$ & $P_{(1,4)},-0.20$ & $P_{(1,5)},-0.08$ & $P_{(1,6)}, 0.62$ & $\mathrm{P}(0.21)$ & $0.96^{* *}$ \\
\hline 3 & Number of nodes & $\mathrm{P}_{(3,1)}, 0.17$ & $\mathrm{P}_{(3,2)}, 0.38$ & & $\mathrm{P}_{(3,4)},-0.15$ & $P_{(3,5)},-0.11$ & $\mathrm{P}_{(3,6)}, 0.47$ & $\mathrm{P}(0.03)$ & $0.79 * *$ \\
\hline 4 & Internodes Length & $\mathrm{P}_{(4,1)}, 0.19$ & $\mathrm{P}_{(4,2)}, 0.39$ & $\mathrm{P}_{(4,3)}, 0.02$ & & $\mathrm{P}_{(4,5)},-0.14$ & $\mathrm{P}_{(4,6)}, 0.56$ & $\mathrm{P}(-0.22)$ & $0.80 * *$ \\
\hline 5 & Cane diameter & $\mathrm{P}_{(5,1)}, 0.08$ & $\mathrm{P}_{(5,2)}, 0.25$ & $\mathrm{P}_{(5,3)}, 0.02$ & $\mathrm{P}_{(5,4)},-0.16$ & & $\mathrm{P}_{(5,6)}, 0.39$ & $\mathrm{P}(-0.19)$ & 0.39 \\
\hline \multirow[t]{2}{*}{6} & $\begin{array}{l}\text { Number of } \\
\text { millablecane }\end{array}$ & $\mathrm{P}_{(6,1)}, 0.20$ & $\mathrm{P}_{(6,2)}, 0.41$ & $\mathrm{P}_{(6,3)}, 0.02$ & $P_{(6,4)},-0.19$ & $P_{(6,5)},-0.12$ & & $\mathrm{P}(0.63)$ & $0.96 * *$ \\
\hline & Residual & \multicolumn{8}{|c|}{0.02} \\
\hline
\end{tabular}


Table 3. Path index of 16 sugarcane genotypes evaluated as two plant crops during 2012-13 and 2013-14

\begin{tabular}{|c|c|c|}
\hline S. No. & Genotype name & Path index \\
\hline 1. & MS-91-CP-523 & 240.39 \\
\hline 2. & S-92-US-72 & 205.21 \\
\hline 3. & Mardan-93 & 198.85 \\
\hline 4. & CP-77/400 & 193.69 \\
\hline 5. & MS-2003-HS-274 & 191.79 \\
\hline 6. & MS-2000-Ho-360 & 188.12 \\
\hline 7. & MS-99-Ho-6 & 185.89 \\
\hline 8. & MS-91-CP-249 & 182.75 \\
\hline 9. & MS-92-CP-99 & 182.72 \\
\hline 10. & MS-2000-Ho-357 & 181.72 \\
\hline 11. & MS-2000-Ho-115 & 178.84 \\
\hline 12. & MS-2000-Ho-535 & 174.59 \\
\hline 13. & MS-2003-HS-366 & 169.70 \\
\hline 14. & MS-91-CP-248 & 168.39 \\
\hline 15. & S-98-SSG-612 & 164.33 \\
\hline 16. & S-98-SSG-363 & 147.57 \\
\hline
\end{tabular}

\section{Conclusion and Recommendations}

Path analysis revealed that most of the parameters are correlated with each other however number of tillers, plant height, number of millablecane, number of nodes are the most important characters directly contributing to yield and could be used as selection criteria for improving cane yield. Looking at the results of the study it can be concluded that path analysis procedure followed by development of path index for selection of sugarcane genotypes could be fruitful in improving overall selection strategies. On the basis of good performances genotype MS-91-CP-523 and genotype S-92US-72 was recommended for further evaluation in uniform yield trials and on farmer's fields under plant crop conditions under the agro climatic conditions of Khyber Pakhtunkhwa.

\section{Author's contributions}

Conceived and designed the experiments: A Ali \& M Tahir, Performed the experiment: A Ali \& NU Haq, Analyzed the data: A Ali \& M Ismail, Contributed materials/ analysis tools: A Ali \& M Tahir, Wrote the paper: A Ali \& N Hayat.

\section{References}

1. FAOSTAT (2016).

2. Sundaresan K, Balasundaram $\mathrm{N}$ \& Shunmugasundaram S (1979). Correlation between seedlings and their settlings in intervarietal crosses of sugarcane for major economic characters. Indian J Agric Sci 49(12): 934-937.

3. Kang MS, Miller JD \& Tai PYP (1983). Genetic and phenotypic path analyses and heritability in Sugarcane. Crop Sci 23(4): 643-647.

4. Singh RK \& Chaudhary BD (1977). Biometrical methods in quantitative genetic analysis.

5. Tahir M, Khalil IH \& Rahman H (2014). Evaluation of important characters for improving cane yield in sugarcane (saccharum sp.). Sar J Agric 30(3): 319323.

6. Yakubu A (2010). Path coefficient and path Analysis of body weight and biometric traits of Yankasa lambs. 
Slovak J Anim Sci 43(1): 17-25

7. Tahir M, Rahman H, Gul R, Ali A \& Khalid M (2013). Genetic divergence in sugarcane genotypes. Am J Expt Agric 3(1): 102-109.

8. Sanghera GS, Tyagi V, Kumar R, Thind KS \& Sharma B (2015). Genetic variability, association and their dissection through path analysis for cane yield and its component traits in early maturing sugarcane clones. J Agric Sci 5(1): 28-34

9. Tyagi AP \& Lal P (2007). Correlation and path coefficient analysis in sugarcane. The South Paci J of Nat Appl Sci, 25(1): 1-9.

10. Chaudhary RR \& Joshi BK (2005). Correlation and path coefficient analyses in sugarcane. Nepal Agric Res J 6: 2834. 